\title{
Areal distribution of the oxygen-isotope ratio in Greenland
}

\author{
H. Jay Zwally, Mario B. Giovinetto ${ }^{2}$ \\ ${ }^{1}$ Code 971, NASA/Goddard Space Flight Center, Greenbelt, MD 20771, U.S.A. \\ ${ }^{2}$ Earth Sciences 356, University of Calgary, Calgary, Alberla T2N IN4, Canada
}

\begin{abstract}
Mean values of the oxygen-isotope ratio relative to standard mean ocean water $\left(\delta^{18} \mathrm{O}\right.$, in \%o reported for 46 sites on the Greenland ice sheet are compiled together with data on mean annual surface temperature, latitude, $\delta^{18} \mathrm{O}$ elevation, and mean annual shortest distance to the open ocean denoted by the $10 \%$ sea-ice concentration boundary. Stepwise regression analyses, with $\delta^{18} \mathrm{O}$ as the dependent variable, define two robust models. In the forward mode at the $99.9 \%$ confidence level, only temperature enters the model. In the backward mode at the $95 \%$ confidence level, only temperature, latitude and distance to the open ocean remain in the model. Inversions of the models on the basis of 160 gridpoint locations $100 \mathrm{~km}$ apart in the area delimited by the surface equilibrium line produce four contoured distributions of $\delta^{18} \mathrm{O}$. Two distributions are based on the bivariate model and two on the multivariate model. The second distribution for each model is obtained substituting mean annual surface-temperature values obtained from the Nimbus-7 Temperature Humidity Infrared Radiometer (THIR) database. All four distributions are considered valid, and differences between them are evaluated using contoured anomaly maps. It is suggested that the inversion of the multivariate model using THIR data provides the more reliable pattern for studies of atmospheric advection or for the derivation of ice-flow adjustments for $\delta^{18} \mathrm{O}$ series obtained from deep-core or ablationzone sites.
\end{abstract}

\section{INTRODUCTION}

Multi-year mean values of ${ }^{18} \mathrm{O} /{ }^{16} \mathrm{O}$ relative to standard mean ocean water (SMOW) $\left(\delta^{18} \mathrm{O}\right.$, in \%o) determined from samples collected on the Greenland ice sheet are used in climatological and glaciological investigations (e.g. Reeh and others, 1987b; Clausen and others, 1988; Johnsen and others, 1989). This study presents stepwise statistical analyses based on $\delta^{18} \mathrm{O}$ reported for 46 sites (Fig. la) as the dependent variable, and four independent variables: latitude $\left(L\right.$, in $\left.{ }^{\circ} \mathrm{N}\right)$; surface elevation $(H$, in $\mathrm{m})$; multi-year mean surface temperature $\left(T_{\mathrm{s}}\right.$, in $\left.\mathrm{K}\right)$ normally determined from $10 \mathrm{~m}$ borehole temperature, mean surface temperature in $1979\left(T_{\mathrm{r}}\right.$, in $\left.\mathrm{K}\right)$ obtained by bilinear interpolation from the Nimbus-7 Temperature Humidity Infrared Radiometer (THIR) database (Comiso, 1994); and multi-year mean shortest distance to the open ocean denoted by the $10 \%$ sea-ice concentration boundary $(D$, in $\mathrm{km})$ obtained from the Nimbus-7 Scanning Multichannel Microwave Radiometer (Gloersen and others, 1992). Use of a different sea-ice concentration boundary to denote open ocean (e.g. $20 \%$ open water) does not introduce significant differences in the statistics. The purpose is to define multivariate models applied to a $100 \mathrm{~km}$ grid database (Figure $1 \mathrm{~b}$ ) and produce contoured distributions of $\delta^{18} \mathrm{O}$. These distributions may be used in advection studies (e.g. Johnsen and others, 1989) or to derive ice-flow adjustments (e.g. Reeh and others, 1987a).

In the following sections, the statistics are significant at the $99.99 \%$ confidence level $(F$ statistic under the null hypothesis showing a probability of $P \leq 0.0001$ ) unless stated otherwise. A confidence level selected for a particular model to determine which variables contribute at that level (or better) to the explanation of variation is a separate statistic from the $P$-value attained by the model.

\section{SAMPLE SITE DATABASE}

The initial compilation included data for a total of 62 sites (after the analyses were completed we were informed of a few more sites available for northern Greenland (K. Steffen, personal communication, August 1996)). Data for 46 of the 62 sites were retained for analyses; these are from Müller and others (1977), Schriber and others (1977), Clausen and Hammer (1988), Clausen and others (1988), Johnsen and others (1989), Dansgaard and others (1993), Grootes and others (1993) and Fischer and others (1995). Most of the data for 18 sites from Fischer and others (1995) were obtained by interpolation. Actual values were obtained after the analyses were completed (H. Fischer, personal communication, August 1996). The differences between the interpolated and actual values are minor. The largest differences are in elevation; differences in latitude and longitude would introduce small changes in $D$ and $T_{\mathrm{r}}$ values. However, use of the actual values would not introduce significant changes in the statistics presented in this study.

Data for 14 sites were excluded from the analyses because the samples were collected in the ablation zone or in areas of widespread summer melt and percolation. These were Warming Land $\left(81.50^{\circ} \mathrm{N}, 52.0^{\circ} \mathrm{W}\right.$; Reeh and others, 1987b), nine sites in the Thule area centered at approximately $76.5^{\circ} \mathrm{N}, 68^{\circ} \mathrm{W}$ (Reeh and others, 1990$)$, Paakitsoq $\left(69.75^{\circ} \mathrm{N}\right.$, $49.0^{\circ} \mathrm{W}$; Reeh and others, 1991), Storstrommen, $\left(77.40^{\circ} \mathrm{N}\right.$, $23.0^{\circ} \mathrm{W}$; Reeh and others, 1993), and Drill Sites I and II, at approximately $70.00^{\circ} \mathrm{N}, 49.5^{\circ} \mathrm{W}$, and $69.92^{\circ} \mathrm{N}, 49.4^{\circ} \mathrm{W}$, respectively (Clausen and Stauffer, 1988).

The reliability of $T_{\mathrm{r}}$ values interpolated from the THIR database with a resolution of approximately $30 \times 30 \mathrm{~km}$ (Comiso, 1994) was assessed by a simple regression of the form $T=\mathrm{f}(T)(N 48$, where $N$ denotes the number of sites 

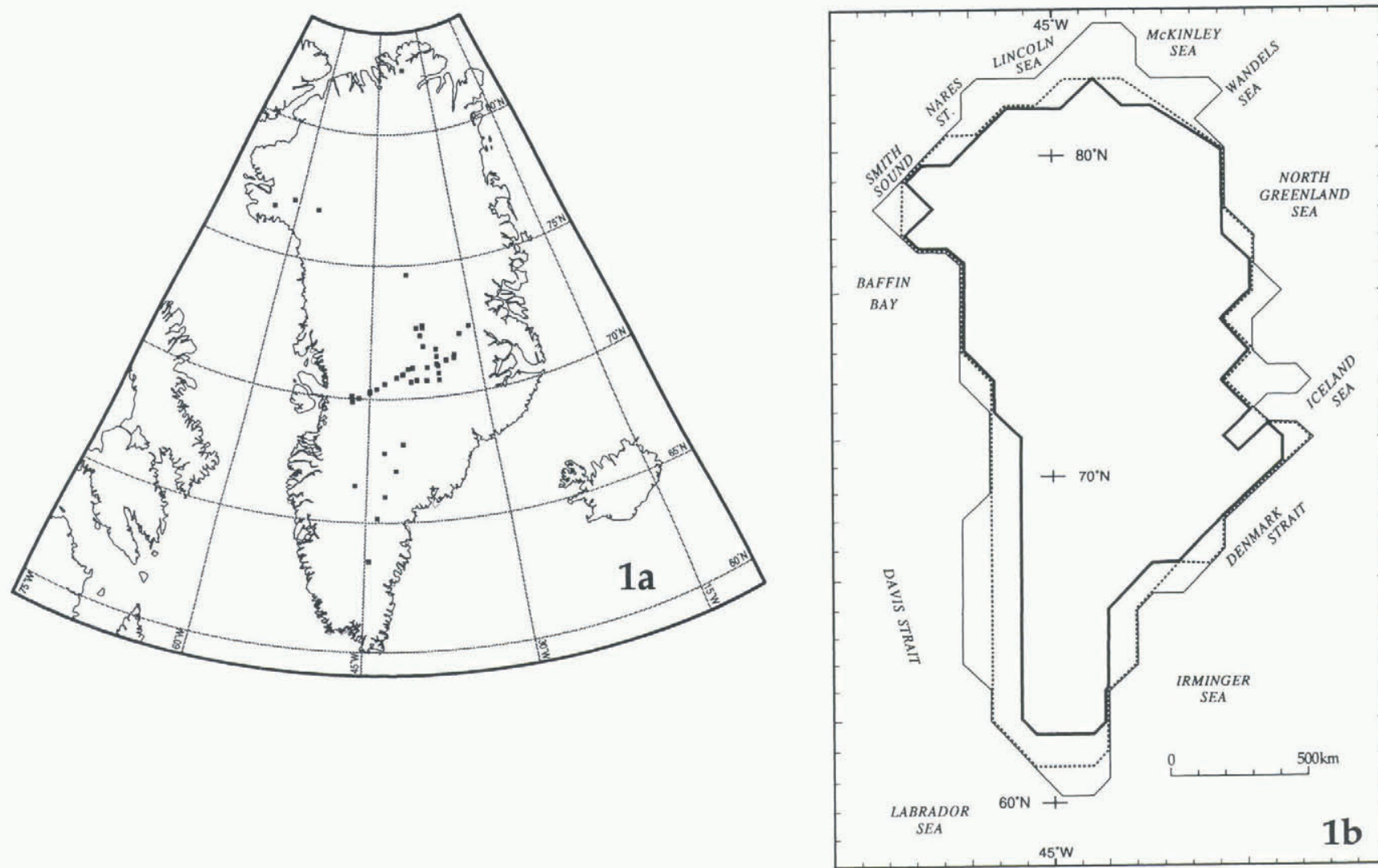

Fig. I. (a) Greenland, showing the location of the 46 data sites for which $\delta^{18} \mathrm{O}$ values have been reported (full squares; some overlap). (b) Schematic map of Greenland. The outer, thin line is roughly coincident with the coastline, enclosing an area represented by 216 gridpoints $100 \mathrm{~km}$ apart. The double line is roughly coincident with the boundary of the conterminous ice sheet, an area represented by 187 gridpoints. The inner, thick line is an approximation to the position of the equilibrium line that encloses an area represented by 160 gridpoints (the boundary of the areas is shown in Figs 2 and 3).

in the set: the coefficient of correlation $(R)$ is 0.966 and the root mean square residual (rms) is 0.81 ). Data for two sites showed the largest departure $(>3 \mathrm{rms}$ ): Site V on the North ice cap, $77.07^{\circ} \mathrm{N}, 70.4^{\circ} \mathrm{W}$ (Müller and others, 1977; Schriber and others, 1977), and a site on the Renland ice cap, (71.25 N, 27.5 W; Johnsen and others, 1992; Hansson, 1994). Data for these sites were excluded from the analyses discussed below.

The descriptive statistics for the N46 set (see Table 1) show that the mean of $T_{\mathrm{r}}$ is practically the same as that of $T_{\mathrm{s}}$, although the standard deviation and range of $T_{\mathrm{r}}$ values are much smaller. Nevertheless, the correlation matrix
(Table 2) shows that where there is strong correlation between $T_{\mathrm{s}}$ and other variables $\left(\delta^{18} \mathrm{O}, H\right)$, these remain strong when $T_{\mathrm{r}}$ is substituted. The stepwise analysis of $\delta^{18} \mathrm{O}$ $=\mathrm{f}\left(L, H, T_{\mathrm{s}}, D\right)$ at the $99.9 \%$ confidence level shows that $T_{\mathrm{s}}$ is the only variable to enter the model in the forward mode or remain in the model in the backward mode (Table 3), defining a robust bivariate model $(R$ is $0.986, \mathrm{rms}$ is 0.55 ):

$$
\delta^{18} \mathrm{O}=-202.172+0.691 T_{\mathrm{s}}
$$

The same result is obtained from runs in the forward mode at the $95 \%$ and $90 \%$ confidence levels. However, the result from runs at these confidence levels in the backward

Table 1. Descriptive statistics

\begin{tabular}{|c|c|c|c|c|c|c|}
\hline \multirow[t]{2}{*}{$(N 46)$} & $\delta^{18} \mathrm{O}$ & $L$ & $H$ & $T_{\mathrm{s}}$ & $T_{t}$ & D \\
\hline & $\%$ & ${ }^{\circ} \mathrm{N}$ & $\mathrm{m}$ & $\mathrm{K}$ & $\mathrm{K}$ & $\mathrm{km}$ \\
\hline Mean: & -31.55 & 71.17 & 2714 & 246.7 & 246.7 & 637 \\
\hline Std dev: & 3.23 & 3.13 & 502 & 4.6 & 3.1 & 231 \\
\hline Minimum & -36.75 & 63.55 & 1300 & 240.7 & 243.0 & 232 \\
\hline Maximum: & -25.30 & 82.49 & 3238 & 256.6 & 252.7 & 1398 \\
\hline \multirow[t]{2}{*}{ (N160) } & & $L_{\mathrm{i}}$ & $H_{\mathrm{i}}$ & $T_{\mathrm{si}}$ & $T_{\mathrm{ri}}$ & $D_{\mathrm{i}}$ \\
\hline & & $\mathrm{N}$ & $\mathrm{m}$ & $\mathrm{K}$ & $\mathrm{K}$ & $\mathrm{km}$ \\
\hline Mean: & & 73.32 & 2188 & 249.1 & 248.7 & 677 \\
\hline Std dev: & & 4.89 & 603 & 5.8 & 4.5 & 297 \\
\hline Minimum: & & 62.30 & 600 & 241.0 & 242.5 & 130 \\
\hline Maximum: & & 82.00 & 3200 & 263.00 & 261.0 & 1365 \\
\hline
\end{tabular}


Table. 2. Correlation matrices

\begin{tabular}{|c|c|c|c|c|c|c|c|}
\hline \multirow[t]{2}{*}{$(N 46)$} & \multicolumn{2}{|l|}{$\delta^{18} \mathrm{O}$} & $L$ & $H$ & $T_{\mathrm{s}}$ & $T_{\mathrm{r}}$ & $D$ \\
\hline & \multicolumn{2}{|l|}{$\%$} & $\mathrm{~N}$ & $\mathrm{~m}$ & $\mathrm{~K}$ & $\mathrm{~K}$ & $\mathrm{~km}$ \\
\hline$\delta^{18} \mathrm{O}$ & 1.000 & & -0.228 & -0.872 & 0.986 & 0.962 & -0.176 \\
\hline$L$ & -0.228 & & 1.000 & 0.211 & -0.266 & -0.178 & 0.809 \\
\hline$H$ & -0.872 & & -0.211 & 1.000 & -0.873 & -0.896 & -0.207 \\
\hline$T_{s}$ & 0.986 & & -0.266 & -0.873 & 1.000 & 0.966 & -0.181 \\
\hline$T_{\mathrm{r}}$ & 0.962 & & -0.178 & -0.896 & -0.966 & 1.000 & -0.125 \\
\hline$D$ & -0.176 & & 0.809 & -0.207 & -0.181 & -0.125 & 1.000 \\
\hline \multirow[t]{2}{*}{$(N 160)$} & $\left(\delta^{18} \mathrm{O}\right)_{\mathrm{ms}}$ & $\left(\delta^{18} \mathrm{O}\right)_{\operatorname{mir}}$ & $L_{\mathrm{i}}$ & $H_{\mathrm{i}}$ & $T_{\mathrm{si}}$ & $T_{\mathrm{ri}}$ & $D_{\mathrm{i}}$ \\
\hline & $\%$ & $\%$ & ${ }^{\circ} \mathrm{N}$ & $\mathrm{m}$ & K & $\mathrm{K}$ & $\mathrm{km}$ \\
\hline$\left(\delta^{18} \mathrm{O}\right)_{\mathrm{mx}}$ & 1.000 & 0.937 & -0.410 & -0.684 & 0.996 & 0.950 & -0.488 \\
\hline$\left(\delta^{18} \mathrm{O}\right)_{\text {mi }}$ & 0.937 & 1.000 & -0.282 & -0.727 & 0.920 & 0.994 & 0.467 \\
\hline$L_{\mathrm{i}}$ & -0.410 & -0.282 & 1.000 & -0.353 & -0.471 & -0.368 & 0.729 \\
\hline$H_{\mathrm{i}}$ & -0.684 & -0.727 & 0.353 & 1.000 & -0.633 & -0.672 & -0.054 \\
\hline$T_{\mathrm{si}}$ & 0.996 & 0.920 & -0.471 & -0.633 & 1.000 & 0.942 & -0.492 \\
\hline$T_{\mathrm{ri}}$ & 0.950 & 0.994 & -0.368 & -0.672 & 0.942 & 1.000 & -0.481 \\
\hline$D_{\mathrm{i}}$ & -0.488 & -0.467 & 0.729 & -0.054 & -0.492 & -0.481 & 1.000 \\
\hline
\end{tabular}

Table 3. Summary of stepwise regression analyses ( $N 46, \delta^{18} \mathrm{O}$ as the dependent variable)

\begin{tabular}{|c|c|c|c|c|c|c|c|c|c|}
\hline \multirow{2}{*}{$\begin{array}{l}\text { Conf. } \\
\text { level }\end{array}$} & \multirow{2}{*}{$\begin{array}{l}\text { Step } \\
\mathrm{F} / \mathrm{B}\end{array}$} & \multicolumn{2}{|c|}{ Independent variation } & \multirow{2}{*}{$\begin{array}{c}R \\
\text { (model) }\end{array}$} & \multicolumn{4}{|c|}{ Partial correlations $\left(R_{\mathrm{p}}\right)$} & \multirow{2}{*}{$\begin{array}{c}r m s \\
\text { (model) }\end{array}$} \\
\hline & & Inc. & Exc. & & $L$ & $H$ & $T$ & $D$ & \\
\hline$>99 \%$ & $\begin{array}{l}\mathrm{F} 0 \\
\mathrm{~F} 1^{*}\end{array}$ & $T$ & $\overline{L, H}, D$ & $\overline{-}_{0.986}$ & $\begin{array}{l}0.228 \\
0.212\end{array}$ & $\begin{array}{l}-0.872 \\
-0.148\end{array}$ & 0.986 & $\begin{array}{c}-0.176 \\
0.009\end{array}$ & $\begin{array}{r}468.28 \\
0.55\end{array}$ \\
\hline $95 \%$ & $\begin{array}{l}\mathrm{B} 0 \\
\mathrm{Bl}^{\dagger}\end{array}$ & $\begin{array}{c}\text { all } \\
L, T, D\end{array}$ & $\bar{H}$ & $\begin{array}{l}0.988 \\
0.987\end{array}$ & - & $\overline{0.156}$ & - & - & $\begin{array}{l}0.53 \\
0.53\end{array}$ \\
\hline
\end{tabular}

* Same results as a run in the backward mode at a confidence level $>99 \%$; step B3: i.e. $T$ remains in the model, and $H, D$ and $L$ are removed in that order. Also, same results as runs in the forward mode at the $95 \%$ and $90 \%$ confidence levels.

$\dagger$ Best model. Same results as a run in the backward mode at the $90 \%$ confidence level.

mode is different: $L, T_{\mathrm{s}}$ and $D$ remain in the model, and $H$ is removed. This stepwise model is equally robust ( $R$ is 0.987 , rms is 0.53 ):

$$
\begin{aligned}
\delta^{18} \mathrm{O}= & -211.082+0.104 L+0.700 T_{8} \\
& +(-1.085 E-3 D)
\end{aligned}
$$

The practically equal $R$ and rms values for Equations (1) and (2) indicate that both models provide the same reliability. Nevertheless, the inclusion of $L$ and $D$ in Equation (2) enhances model sensitivity to predict $\delta^{18} \mathrm{O}$; this is substantiated by the results of inversions of Equations (1) and (2) using gridpoint data, described below.

\section{GRIDPOINT DATABASE}

The gridpoint locations were determined from a pattern with origin lines at $135^{\circ} \mathrm{W}-45^{\circ} \mathrm{E}$, and $45^{\circ} \mathrm{W}$. The 160 locations that lie in the area of net accumulation at the surface were selected on the basis of an assumed north to south linear variation of the elevation of the equilibrium line (Giovinetto and Zwally, 1996). The variation was not adjusted for differences between north and south facing slopes (e.g. Benson, 1962), or between eastern and western flanks at particular latitudes (e.g. Reeh, 1985) because it does not affect the findings of our study.
The gridpoint data $(N 160)$ on latitude $\left(L_{\mathrm{i}}\right.$, in $\left.^{\circ} \mathrm{N}\right)$, surface elevation $\left(H_{\mathrm{i}}\right.$, in m.), and mean annual surface temperature $\left(T_{\mathrm{si}}\right.$ in $\left.\mathrm{K}\right)$ were obtained by visual interpolation from the surface contour and isotherm maps of Ohmura (1987). The $T_{\mathrm{ri}}$ and $D_{\mathrm{i}}$ data were obtained as described for $T_{\mathrm{r}}$ and $D$ in the sample site database. The descriptive statistics for the N160 set are listed in Table 1 .

The gridpoint database was compiled before the publication of a more recent topographic map. We compared $H_{\mathrm{i}}$ and surface elevation values obtained (i) by visual interpolation from the latest surface contours map (Weidick, 1995), and (ii) by bilinear interpolation from the ERS-1 radar-altimeter data. The comparisons are based on data for 168 gridpoint locations that include about 130 of the 160 used in this study. We obtained $R$ values between 0.951 and 0.953 . The difference in elevation values obtained from each surface contour map is due, in part, to the overlay of a fixed-grid pattern over maps of different projections and with different standard lines. The differences between these and the elevation values obtained from the ERS-1 database is due, in part, to round off (to $\left.0.1^{9}\right) L_{\mathrm{i}}$ and longitude values entered in the gridpoint database. This implies an error in location of several $\mathrm{km}$ north to south and in most areas of at least $1 \mathrm{~km}$ east to west, whereas the ERS-1 data resolution is of about $500 \mathrm{~m}$ (Wingham, 1995). Therefore, we did not update the $H_{\mathrm{i}}$ data. 


\section{AREAL DISTRIBUTION OF $\delta^{18} \mathrm{O}$}

The inversions of Equation (1) using the $N 160$ database and either $T_{\mathrm{si}}$ or $T_{\mathrm{ri}}\left(\right.$ i.e. $\left(\delta^{18} \mathrm{O}\right)_{\mathrm{bs}}=\mathrm{f}\left(T_{\mathrm{si}}\right)$, and $\left.\left(\delta^{18} \mathrm{O}\right)_{\mathrm{br}}=\mathrm{f}\left(T_{\mathrm{ri}}\right)\right)$ result in mean, maximum and minimum values that are remarkably close to those obtained by the inversions of Equation (2) (i.e. $\left(\delta^{18} \mathrm{O}\right)_{\mathrm{ms}}=\mathrm{f}\left(\mathrm{L}_{\mathrm{i}}, T_{\mathrm{si}}, D_{\mathrm{i}}\right.$ ), and $\left(\delta^{18} \mathrm{O}\right)_{\mathrm{mr}}=\mathrm{f}\left(L_{\mathrm{i}}\right.$, $T_{\mathrm{ri}}, D_{\mathrm{i}}$ ) (Table 4). The correlation matrix for the $N 160$ set (Table 2) lists the strong correlations that would be expected from Equations (1) and (2) between the derived terms $\left(\delta^{18} \mathrm{O}\right)_{\mathrm{ms}},\left(\delta^{18} \mathrm{O}\right)_{\mathrm{mr}}$ and the input terms $T_{\mathrm{si}}$ and $T_{\mathrm{ri}}(R$ values of 0.996 and 0.994 ). The covariation between $H_{\mathrm{i}}$ and the temperature terms ( $R$ values of 0.633 and 0.672 ) is weak relative to the strong covariation noted for the sample sites data (Table 2, N46: $R$ values of 0.873 and 0.986 ). This decay is also noted in the relationship between $\delta^{18} \mathrm{O}$ and elevation ( $R$ is 0.872 for the sample site data, and $R$ values are 0.684 and 0.727 for the gridpoint data).

The distributions of $\left(\delta^{18} \mathrm{O}\right)_{\mathrm{bs}}$ and $\left(\delta^{18} \mathrm{O}\right)_{\mathrm{br}}$ as well as of $\left(\delta^{18} \mathrm{O}\right)_{\mathrm{ms}}$ and $\left(\delta^{18} \mathrm{O}\right)_{\mathrm{mr}}$ (Figs $2 \mathrm{a}, \mathrm{b}$ and $3 \mathrm{a}, \mathrm{b}$, respectively) show that, in general, the isopleths are oriented perpendicular to flow lines (e.g. Radok and others, 1982), thus facilitating any derivation of adjustments for $\delta^{18} \mathrm{O}$ series obtained from deep cores.

We evaluate first the difference between bivariate models using either $T_{\mathrm{si}}$ or $T_{\mathrm{ri}}$ data (i.e. $\Delta_{\mathrm{b}}=\left[\left(\delta^{18} \mathrm{O}\right)_{\mathrm{bs}}\right.$ $\left.-\left(\delta^{18} \mathrm{O}\right)_{\mathrm{br}}\right]$ (Fig. 2c). The distribution of $\Delta_{\mathrm{b}}$ indicates differences of $-1 \%$ in the north-central region, changing to $+1 \%$ in the south-central region. In these regions lie most of the length of the main drainage divides, where flow lines originate. In general, $\Delta_{b}$ becomes larger toward the equilibrium line, except in four regions where it decreases to zero: these are the sectors of the Smith Sound-Nares Strait, McKinley Sea, southern North Greenland Sea-northern Iceland Sea, and southern Denmark Strait. Otherwise, $\Delta_{\mathrm{b}}$ remains positive in the southern outlying slopes, i.e. toward the equilibrium line in the sectors of the Davis Strait $(+3 \%$ ), Labrador Sea $(+2 \%)$ and Irminger Sea $(+4 \%)$. It also

Table 4. Descriptive statistics of predicted $\delta^{18} \mathrm{O}$ values ${ }^{*}$ and $\delta^{18} \mathrm{O}$ anomalies ${ }^{\dagger}$

\begin{tabular}{|c|c|c|c|c|c|c|c|}
\hline \multirow[t]{2}{*}{$(N 160)$} & $\left(\delta^{18} \mathrm{O}\right)_{\mathrm{bs}}$ & $\left(\delta^{18} \mathrm{O}\right)_{\mathrm{br}}$ & $\left(\delta^{18} \mathrm{O}\right)_{\mathrm{ms}}$ & $\left(\delta^{18} \mathrm{O}\right)_{\mathrm{mr}}$ & $\Delta_{\mathrm{b}}$ & $\Delta_{\mathrm{m}}$ & $\Delta_{\mathrm{r}}$ \\
\hline & $\%$ & $\%$ & $\%$ & $\%$ & $\%$ & $\%$ & $\%$ \\
\hline Mean: & -30.02 & -30.35 & -29.80 & -30.13 & 0.33 & 0.34 & -0.22 \\
\hline Std Dev:: & 4.00 & 3.08 & 3.99 & 3.11 & 0.12 & 0.12 & 0.03 \\
\hline Minimum: & -35.64 & -34.63 & -35.66 & -34.41 & -3.39 & 3.43 & -1.18 \\
\hline Maximum: & -20.44 & 21.84 & -19.89 & -21.31 & 4.35 & 4.41 & 0.40 \\
\hline
\end{tabular}

* $\left(\delta^{18} \mathrm{O}\right)_{\mathrm{bs}}=\mathrm{f}\left(T_{\mathrm{si}}\right) ;\left(\delta^{18} \mathrm{O}\right)_{\mathrm{br}}=\mathrm{f}\left(T_{\mathrm{ri}}\right) ;\left(\delta^{18} \mathrm{O}\right)_{\mathrm{ms}}=\mathrm{f}\left(L_{\mathrm{i}}, T_{\mathrm{si}}, D_{\mathrm{i}}\right) ;\left(\delta^{18} \mathrm{O}\right)_{\mathrm{mr}}=\mathrm{f}\left(L_{\mathrm{i}}, T_{\mathrm{ri}}, D_{\mathrm{i}}\right)$

${ }^{\dagger} \Delta_{\mathrm{b}}=\left[\left(\delta^{18} \mathrm{O}\right)_{\mathrm{bs}}-\left(\delta^{18} \mathrm{O}\right)_{\mathrm{br}}\right]: \Delta_{\mathrm{m}}=\left[\left(\delta^{18} \mathrm{O}\right)_{\mathrm{mix}}-\left(\delta^{18} \mathrm{O}\right)_{\mathrm{mrr}}\right]: \Delta_{\mathrm{r}}=\left[\left(\delta^{18} \mathrm{O}\right)_{\mathrm{br}}-\left(\delta^{18} \mathrm{O}\right)_{\mathrm{mr}}\right]$.
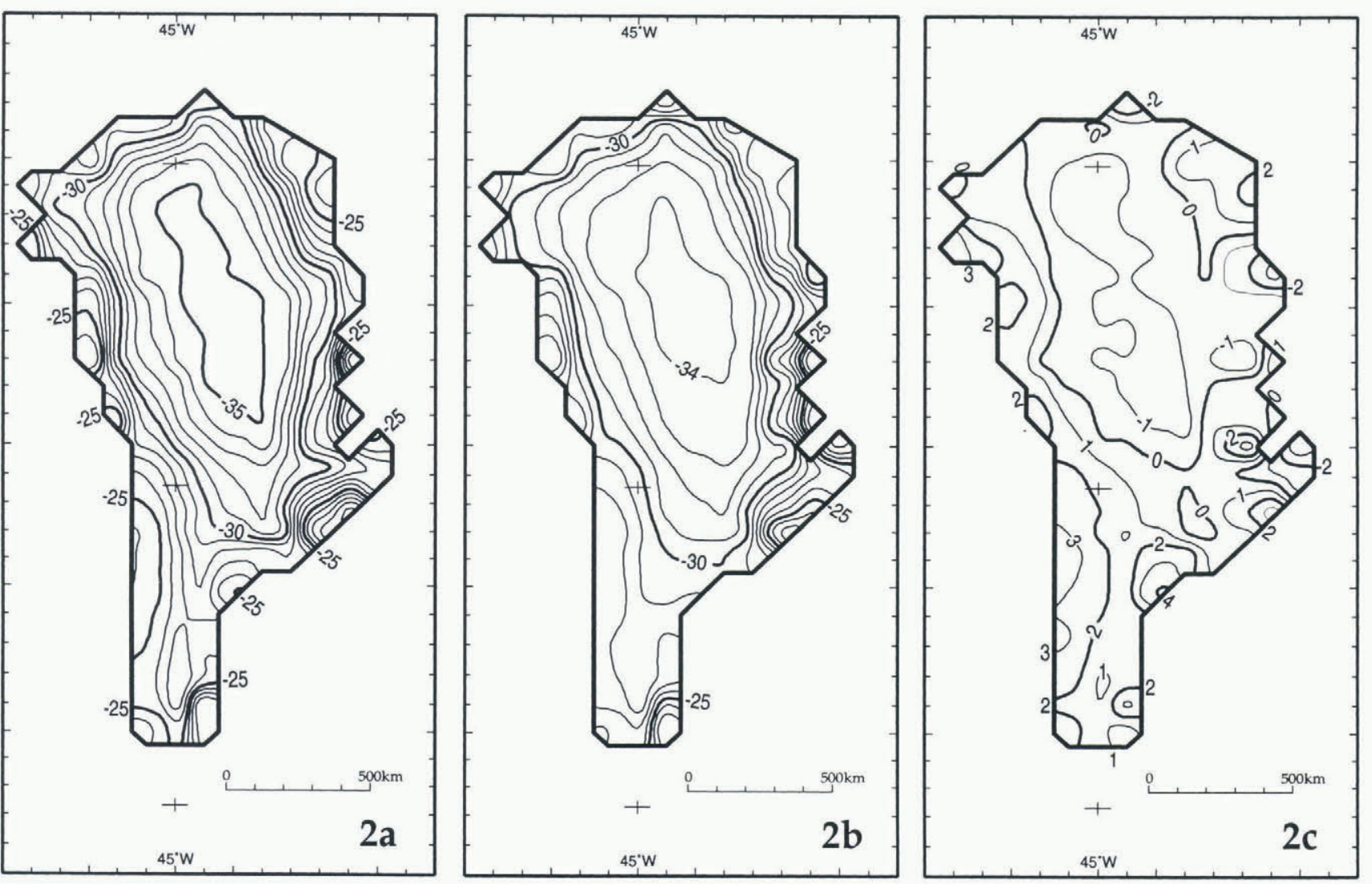

Fig. 2. The area of Greenland delimited by the equilibrium line. (a) Distribution of $\left(\delta^{18} \mathrm{O}\right)_{\mathrm{bs}}=\mathrm{f}\left(T_{\mathrm{si}}\right)$. (b) Distribution of $\left(\delta^{18} \mathrm{O}\right)_{\mathrm{br}}=\mathrm{f}\left(T_{\mathrm{ri}}\right)$. (c) Distribution of $\Delta_{\mathrm{b}}=\left(\delta^{18} \mathrm{O}\right)_{\mathrm{bs}}-\left(\delta^{18} \mathrm{O}\right)_{\mathrm{br}}$. 

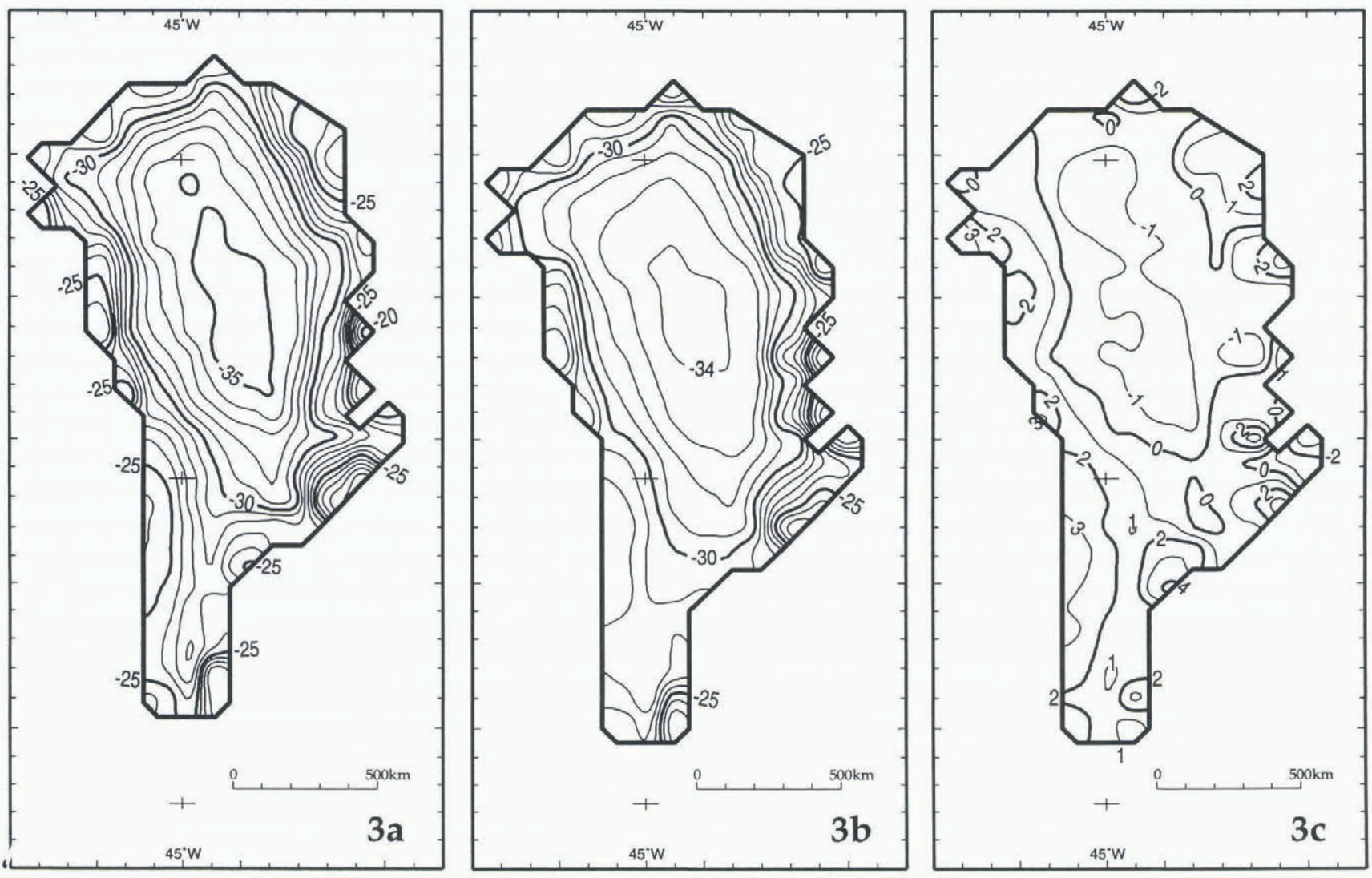

Fig. 3. The area of Greenland delimited by the equilibrium line. (a) Distribution of $\left(\delta^{18} \mathrm{O}\right)_{\mathrm{ms}} \cdot\left(\right.$ b) Distribution of $\left(\delta^{18} \mathrm{O}\right)_{\mathrm{mr}}$. (c) Distribution of $\Delta_{\mathrm{m}}=\left(\delta^{18} \mathrm{O}\right)_{\mathrm{ms}}-\left(\delta^{18} \mathrm{O}\right)_{\mathrm{mr}}$.

becomes larger toward the equilibrium line, but the increases are signed in a complex pattern in the sectors of the Denmark Strait-Iceland Sea $(+3 \%$, decreasing northward to $-3 \%$ ), and around the northern outlying slopes in the sectors of Baffin Bay $(+2 \%)$, the Lincoln and western McKinley Seas $(-2 \%)$, the Wandels Sea $(+1 \%)$, and the North Greenland Sea (from $+2 \%$ in the central part of the sector, to $-3 \%$ in the southern part).

Due to the dominance of the temperature term in both Equations (1) and (2), the difference between multivariate models using either $T_{\mathrm{si}}$ or $T_{\mathrm{ri}}$ data (i.e. $\Delta_{\mathrm{m}}\left[\left(\delta^{18} \mathrm{O}\right)_{\mathrm{ms}}\right.$ $\left.-\left(\delta^{18} \mathrm{O}\right)_{\mathrm{mr}}\right]$, is practically identical (Figure $\left.3 \mathrm{c}\right)$. This similarity is also noted in the descriptive statistics, which show insignificant differences between $\Delta_{\mathrm{b}}$ and $\Delta_{\mathrm{m}}$ (Table 4).

We evaluate next the difference introduced by the multivariate models that include the effects of latitude and distance to the open ocean. For this, we select the models that include $T_{\mathrm{r}}$ data, and produce a contoured distribution of $\Delta_{\mathrm{r}}=\left(\delta^{18} \mathrm{O}\right)_{\mathrm{br}}-\left(\delta^{18} \mathrm{O}\right)_{\mathrm{mr}}$ (Fig. 4, Table 4). The difference in distribution introduced by the multivariate model is small (mean $-0.22 \%$, std dev. 0.03). The larger $\Delta_{\mathrm{r}}$ values are noted in the northwest region of the ice sheet (between $-0.50 \%$ and $-1.15 \%$ ), decreasing to zero in a broad zone extending from the sector of Baffin Bay to the Irminger Sea sector. Values of $\Delta_{\mathrm{r}}$ increase toward the southern region of the ice sheet (between $+0.10 \%$ and $+0.35 \%$ ).

\section{DISCUSSION AND GONGLUSIONS}

At present, given the relatively small number and sporadic areal distribution of firn-temperature measurements at depths $>10 \mathrm{~m}$, and the paucity of meteorological records

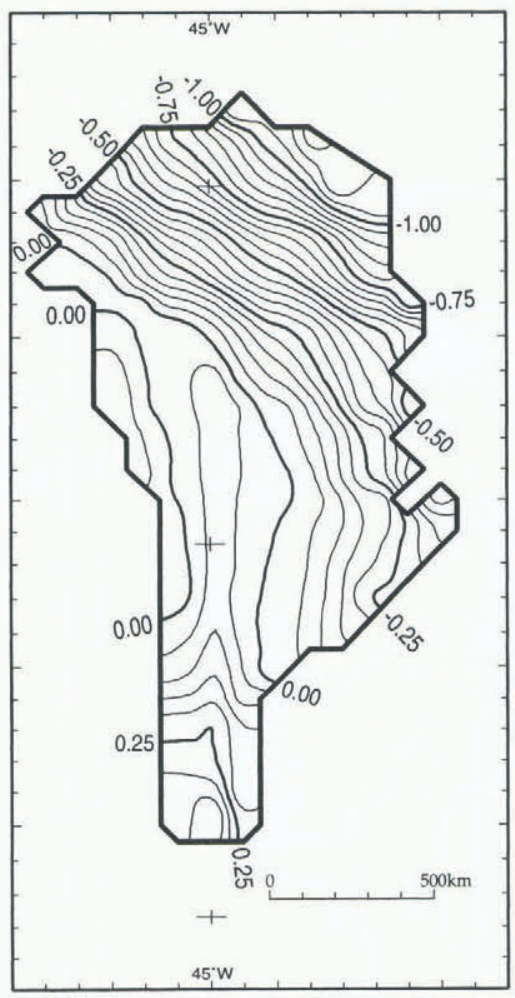

Fig. 4. The area of Greenland delimited by the equilibrium line. Distribution of $\Delta_{\mathrm{r}}=\left(\delta^{18} \mathrm{O}\right)_{\mathrm{br}}-\left(\delta^{18} \mathrm{O}\right)_{\mathrm{mr}}$.

from the interior (manned as well as automatic weather stations), we believe that the distribution of $\left(\delta^{18} \mathrm{O}\right)_{\mathrm{ms}}$ (Fig. 3b) is the more reliable pattern. The reliability of this pattern, as well as that produced using $\left(\delta^{18} \mathrm{O}\right)_{\mathrm{ms}}$ (Fig. 2b) may be improved if $\delta^{18} \mathrm{O}$ values for the sample sites could be adjusted to represent only the last 10-20 years of records available at 
each site (some of the $\delta^{18} \mathrm{O}$ values entered in the database are from samples spanning at least a few centuries).

The distribution of $\left(\delta^{18} \mathrm{O}\right)_{\mathrm{mr}}$ is produced from the inversion of a robust multivariate model that includes Nimbus-7 THIR mean annual temperature data, latitude and mean annual shortest distance to the open ocean $(R$ is $0.987, \mathrm{rms}$ is 0.53 ). It shows large differences relative to the distribution produced using a bivariate model based on temperature values interpolated from surface data $\left(\Delta_{\mathrm{m}}=0.34 \pm 0.12 \%\right.$, with a range of $-3.43 \%$ to $+4.41 \%$ ). The larger differences show in the outer slopes, i.e. the zone characterized by steep surface gradient close to the equilibrium line. These are the areas where interpolation of surface-temperature data would be least reliable. Nevertheless, in more than half the accumulation area of the ice sheet, in the interior where the main drainage divides lie, the difference is $-1 \%$ in the north and central part, and $+1 \%$ in the southern part.

The distribution of $\left(\delta^{18} \mathrm{O}\right)_{\mathrm{mr}}$ also shows differences from a distribution based on a bivariate model using only Nimbus-7 THIR data. The inclusion of latitude and distance to the open ocean induces differences $\left(\Delta_{\mathrm{r}}=0.22 \pm 0.02 \%\right.$, with a range of -1.18 to $0.40 \%$ ) that are smaller than the error of prediction in more than three-quarters the accumulation area of the ice sheet. The only differences larger than the error are found in the northwest region of the ice sheet.

\section{ACKNOWLEDGEMENTS}

The authors gratefully acknowledge the contributions of D. Bromwich, H. Fischer, D. Fisher, K. Kuivinen and L. Lay to locate data sources; of S. Bertazzon, S. Fiegles, S. Gammell, R. Poitras and T. Seiss with data processing; and of V. Morgan, E. Steig, and N. Waters for reviewing the manuscript.

\section{REFERENCES}

Benson, C. S. 1962. Stratigraphic studies in the snow and firn of the Greenland ice sheet. SIPRE Res. Rep. 70.

Clausen, H. B. and C. U. Hammer. 1988. The Laki and Tambora cruptions as revealed in Greenland ice cores from 11 locations. Ann. Glaciol., 10, 16-22.

Clausen, H. B. and B. Stauffer. 1988. Analyses of two ice cores drilled at the ice-sheet margin in West Greenland. Ann. Glaciol., 10, 23-27.

Clausen, H. B., N. S. Gundestrup, S. J. Johnsen, R. Bindschadler and J. Zwally. 1988. Glaciological investigations in the Crète area, central Greenland: a search for a new deep-drilling site. Ann. Glaciol., 10, 10-15.

Comiso, J. C. 1994. Surface temperatures in the polar regions from Nimbus 7 temperature humidity infrared radiometer. f. Geophys. Res, 99 (C3), $5181-5200$.
Dansgaard,W. and 10 others. 1993. Evidence for general instability of past climate from a 250-kyr ice-core record. Nature, 364 6434), 218220.

Fischer, H., D. Wagenbach, M. Laternser and W. Haeberli. 1995. Glaciometeorological and isotopic studies along the EGIG line, central Greenland. 7. Glaciol., 41 (139), 51.5-527.

Giovinetto, M. B. and H. J. Zwally. 1996. An assessment of the mass budgets of Antarctica and Greenland using accumulation derived from remotely sensed data in areas of dry snow. Z. Gletscherkd. Glazialgeol., 31, Part I, $1995,2537$.

Gloersen, P., W. J. Campbell, D. J. Cavalieri, J. C. Comiso, C. L. Parkinson and H. J. Zwally. 1992. Arctic and Antarctic sea ice, 1978-1987: satellite passive-microwave observations and analysis. Washington, DC, National Acronautics and Space Administration. (NASA SP-511,

Grootes, P. M., M. Stuiver, J. W. C. White, S. Johnsen and J. Jouzel. 1993. Comparison of oxygen isotope records from the GISP2 and GRIP Greenland ice cores. Nature, 366 (6455), 552-554.

Hansson, M. E. 1994. The Renland ice core: a Northern Hemisphere record of aerosol composition over 120000 years. Tellus, 46B (5), 390-418.

Johnsen, S. J., W. Dansgaard and J. W. C. White. 1989. The origin of Arctic precipitation under present and glacial conditions. Tellus, 41B 4),452-468.

Johnsen, S. J. and 7 others. 1992. A "deep" ice core from East Greenland. Medd. Gronl., Geoscience 29.

Müller, F., B. Stauffer and G. Schriber. 1977. Isotope measurements and firn stratigraphy on ice caps surrounding the North Water polynya. International Association of Hydrological Sciences Publication 118 (Symposium at Grenoble 1975 - Isotopes and Impurities in Snow and Ice), 188196.

Ohmura, A. 1987. New temperature distribution maps for Greenland. Z Gletscherkd. Glazialgeol., $23(1), 1-45$.

Radok, U., R. G. Barry, D. Jenssen, R. A. Keen, G. N. Kiladis and B. McInnes. 1982. Climatic and physical characteristics of the Greenland ice sheet. Part I and II. Boulder, CO, University of Colorado. Cooperative Institute for Research in Environmental Sciences.

Reeh, N. 1985. Greenland ice-sheet mass balance and sea-level change. In Glaciers, ice sheets, and sea level: effect of a $\mathrm{CO}_{\text {y-induced climatic change. Report }}$ of a Workshop held in Seattle, Washington, September 13 15, 1984. Washington, DC, U.S. Department of Energy. Oflice of Energy Research, 155-171. Report DOE/ER 60235-1.

Reeh, N., C. U. Hammer, H. H. Thomsen and D. A. Fisher. 1987a. Use of trace constituents to test flow models for ice sheets and ice caps. International Association of Hydrological Publication 170 (Symposium at Vancouver 1987 - Phisical Basis of Ice Sheet Modelling , 299-310.

Reeh, N., H. H. Thomsen and H. B. Clausen. 1987b. The Greenland ice sheet margin - a mine for paleo-environmental studies. Palaeogeogr., Palaeoclimatol., Palaeoecol., 58 2), 229-234.

Reeh. N., H. H. Thomsen, P. Frich and H.B. Clausen. 1990. Stable isotope studies on ice margins in the Thule area. Medd. Gronl., Geoscience 22, 47-56.

Reeh, N., H. Oerter, A. Letréguilly, H. Miller and H. -W. Huberten. 1991. A new, detailed ice-age oxygen-18 record from the ice-sheet margin in central West Greenland. Palaeogeogr., Palaeoclimatol., Palaeoecol., 90 4,.373-383.

Reeh, N., H. Oerter and H. Miller. 1993. Correlation of Greenland ice-core and ice-margin $\left(\delta^{18} \mathrm{O}\right)$ records. In Peltier, W.R., ed. Ice in the climate system. Berlin, etc., Springer-Verlag, 481-497. (NATO ASI Series I: Global Environmental Change 12.

Schriber, G. B. Stauffer and F. Müller. $1977 .{ }^{18} 0 /{ }^{16} 0 .{ }^{2} \mathrm{H} / \mathrm{H}$ and ${ }^{3} \mathrm{H}$ measurements on precipitation and air moisture samples from the North Water area. International Association of Hydrological Sciences Publication 118 (Symposium at Grenoble 1975 - Isolopes and Impurities in Snow and Ice), $182-187$.

Weidick. A. 1995. Greenland. U.S. Geol. Surv. Prof. Pap. 1386-C. C1-C93.

Wingham, D. J. 1995. The limiting resolution of ice-sheet elevations derived from pulse-limited satellite altimetry. f. Glaciol., 41 (138), 413-422. 